\title{
UJI AKTIVITAS ANTIOKSIDAN EKSTRAK ETANOL BUAH Psidium guajava L, Melaleuca leucadendron L, Capsicum frutescens L, dan Anethum graveolens L DENGAN METODE DPPH BESERTA PENETAPAN KADAR FENOLIK TOTALNYA
}

\section{ANTIOXIDANT ACTIVITY ASSAY OF ETHANOL EXTRACT OF Psidium guajava L, Melaleuca leucadendron L, Capsicum frutescens L, and Anethum graveolens L FRUIT BY DPPH METHOD WITH DETERMINATION OF TOTAL PHENOLIC CONTENT}

\author{
Rosita Melannisa, Ika Trisharyanti D.K., Andi Suhendi, \\ Muhammad Da'i*, Arief llham Kusuma Atmaja \\ Fakultas Farmasi, Universitas Muhammadiyah Surakarta \\ abulathfi@gmail.com
}

\begin{abstract}
ABSTRAK
Antioksidan alami dari luar tubuh diperlukan untuk mencegah munculnya penyakit karena terpapar oleh radikal bebas yang berlebih. Buah Psidium guajava $L$, Melaleuca leucadendron $L$, Capsicum frutescens $L$ dan Anethum graveolens $L$ diketahui memiliki kandungan fenolik dan flavonoid yang berfungsi sebagai antioksidan. Penelitian ini bertujuan untuk melihat korelasi antara kandungan fenolik total dengan aktivitas antioksidannya. Aktivitas antiradikal ditentukan dengan menggunakan metode DPPH kemudian dihitung nilai Inhibitory Concentration (IC $\left.C_{50}\right)$ yaitu konsentrasi sampel yang mampu menghambat 50\% radikal DPPH. Kandungan fenol ditetapkan dengan menggunakan pereaksi Folin-Ciocalteu dan dihitung sebagai GAE (Gallic Acid Equivalent). Hasil penelitian menunjukkan ekstrak etanol buah Psidium guajava L, Melaleuca leucadendron L, Capsicum frutescens $L$ dan Anethum graveolens $L$ memiliki nilai $I C_{50}$ berturut-turut 167,347; 6,074; 139,801; dan 237,984 $\mu \mathrm{g} / \mathrm{mL}$. Sedangkan nilai GAE berturut-turut 23,73; 257,34; 21,44; 11,78 $\mathrm{mg} / \mathrm{g}$ sampel. Nilai koefisien korelasi antara kandungan fenolik dengan aktivitas antioksidan adalah $R^{2}=0,847$, yang menunjukkan bahwa aktivitas antioksidan dari ekstrak etanol buah yang diuji $84,7 \%$ merupakan kontribusi dari senyawa fenolik.
\end{abstract}

Kata kunci: Antioksidan DPPH, Psidium guajava L, Melaleuca leucadendron L, Capsicum frutescens $L$, Anethum graveolens $L$, Fenolik Total

\section{ABSTRACT}

The body need natural antioxidants from outside to prevent it from the disease caused by exposure of excerssive free radical. Psidium guajava $L$, Melaleuca leucadendron $L$, Capsicum frutescens $L$, and Anethum graveolens $L$ fruits are know contain phenolic and flavonoids that acts as antioxidants. The aims of this study to know the correlation between the phenolic content with antioxidant activity. Radical activity is determined by DPPH method. The content of phenols is determined by using Folin-Ciocalteu reagent and calculated as GAE (Gallic Acid Equivalent). The results show that the ethanol extract Psidium guajava L, Melaleuca leucadendron L, Capsicum frutescens $L$, and Anethum graveolens $L$ fruits has $I C_{50}$ value 167.347; 6.074; 139.801; and $237.984 \mu \mathrm{g} / \mathrm{mL}$ consecutively. While the value of GAE 23.73; 257.34; $21.44 ; 11.78 \mathrm{mg} / \mathrm{g}$ sample consecutively. The correlation coefficient between phenolic content with antioxidant activity is $R^{2}=$ 0.847 , which is indicated that $84.7 \%$ of the antioxidant acativity of the ethanol extract of the fruit were tested contribute by the phenolic compounds.

Key words: Antioxidant DPPH, Psidium guajava L, Melaleuca leucadendron L, Capsicum frutescens $L$, Anethum graveolens $L$, Total Phenolic

\section{PENDAHULUAN}

Radikal bebas merupakan sekelompok zat kimia yang sangat reaktif karena memiliki satu atau lebih elektron yang tidak berpasangan. Radikal bebas merupakan produk normal dari proses metabolisme (Hariyatmi, 2004) atau dapat terbentuk dari luar tubuh (Langseth, 1995). Radikal bebas berperan penting pada kerusakan jaringan dan proses patologi dalam organisme hidup (Velazquez et al., 2003).

Senyawa antioksidan memiliki peran yang sangat penting dalam kesehatan. Karakter utama senyawa antioksidan adalah kemampuannya untuk menangkap radikal bebas (Prakash, 2001 cit Amrun et al., 2007). 
Antioksidan merupakan zat yang dapat menetralkan radikal bebas, atau suatu bahan yang berfungsi melindungi sistem biologi tubuh dari efek merugikan proses reaksi yang menyebabkan oksidasi berlebihan (Hariyatmi, 2004).

Antioksidan tambahan dari luar atau antioksidan eksogen, seperti Vitamin E, Vitamin C maupun berbagai jenis sayuran dan buahbuahan diperlukan untuk menetralkan radikal dalam tubuh (Soeksmanto et al., 2007). Beberapa penelitian menyebutkan bahwa antioksidan alami dihubungkan dengan keberadaan senyawa-senyawa fenolik dan flavonoid (Zou et al., 2004 cit Montoro et al.,2005).

Indonesia adalah negara yang kaya akan sayuran dan buah-buahan, sebagian besar sayuran dan buah-buahan di Indonesia bisa dimanfaatkan sebagai sumber obat alam. Beberapa tanaman antara lain: Jambu biji (Psidium guajava Linn), Kayu putih (Melaleuca leucadendron L), Cabe rawit (Capsicum frutescens L), Adas (Anethum graveolens L). Jambu biji mengandung senyawa fenolik seperti mirisetin dan apigenin (Miean dan Mohamed, 2001 cit Thaipong et al., 2006), ellagic acid, dan antosianin (Misra dan Seshadri, 1968). Kayu putih mengandung saponin, flavonoida dan tanin, di samping minyak atsiri (Thomas, 1992). Cabe rawit mengandung kapsaisin, kapsantin, karotenoid, alkaloid asiri, resin (Anomin, 2005). Adas mengandung 50-60 persen anetol, lebih kurang 20 persen fenkon, pinen, limonen, dipenten, felandren, metilchavikol, anisaldehid, asam anisat.

Oleh karena itu, perlu dilakukan penelitian terhadap korelasi aktivitas antioksidan dan kandungan fenolik ekstrak etanol buah Psidium guajava Linn, Melaleuca leucadendron L, Capsicum frutescens $\mathrm{L}$ dan Anethum graveolens $\mathrm{L}$.

\section{BAHAN DAN METODE ANALISIS}

Bahan yang digunakan yaitu ekstrak etanol buah Psidium guajava L, Melaleuca leucadendron L, Capsicum frutescens $\mathrm{L}$ dan Anethum graveolens $\mathrm{L}$ dari Fakultas Farmasi UMS, DPPH, etanol p.a. (E.Merck), etanol teknis. (E.Merck), alumunium foil, vitamin $\mathrm{E}$ (Sigma Co.), natrium bikarbonat(E.Merk), aquabidestillata.

\section{Uji Aktivitas Antikosidan}

Sejumlah larutan sampel ekstrak etanol buah Psidium guajava Linn, Melaleuca leucadendron L, Capsicum frutescens $\mathrm{L}$ dan Anethum graveolens $\mathrm{L}$ serta vitamin $\mathrm{E}$ dengan volume tertentu, ditempatkan dalam labu takar $5,0 \mathrm{~mL}$. Sampel selanjutnya ditambah dengan $700 \mu \mathrm{L}$ DPPH 0,4 mM dan ditambah etanol p.a hingga tanda. Campuran tersebut divorteks selama 30 detik dan diinkubasi selama 30 menit.

Absorbansi sampel diukur terhadap blangko yang terdiri dari sejumlah larutan stok sampel dalam etanol pada $\lambda_{\max }$. Selain itu, dibandingkan dengan kontrol yang terdiri dari $700 \mu \mathrm{L}$ DPPH $0,4 \mathrm{mM}$ dalam etanol p.a. Dihitung \% aktivitas antiradikal. Dibuat kurva regresi linier antara konsentrasi melawan \% aktivitas antiradikal. Didapatkan rumus regresi linier dan ditentukan konsentrasi sampel pada aktivitas 50\%. Percobaan uji aktivitas antiradikal direplikasi sebanyak tiga kali. Setiap sekali percobaan, pembuatan stok dan pengenceran sampel dibuat pembacaan duplo.

\section{Penentuan Kandungan Fenolik}

Larutan stok ekstrak Melaleuca leucadendron $\mathrm{L}$ dibuat menjadi konsentrasi $0,1 \%$ sedangkan untuk ekstrak Psidium guajava L, Capsicum Frutescens L dan Anethum Graveolens $\mathrm{L}$ dibuat menjadi konsentrasi $0,5 \%$ dan diambil $100 \mu \mathrm{L}$ stok sampel, kemudian direaksikan seperti pada OT, kemudian didiamkan selama OT dan diamati absorbansinya pada $\lambda_{\max }$. Penentuan dilakukan dengan replikasi 3 kali dan pembacaan duplo. Nilai yang diperoleh merupakan ekuivalensi miligram asam galat tiap gram ekstrak (Gallic Acid Equivalent / GAE).

\section{HASIL DAN PEMBAHASAN Uji Aktivitas Antioksidan}

Aktivitas antiradikal ditentukan dari kemampuan sampel uji untuk merubah warna ungu dari DPPH menjadi warna kuning pada panjang gelombang maksimalnya. Pembacaan absorbansi terhadap perubahan warna dilakukan pada waktu tertentu yang memberikan kesempatan yang cukup untuk berlangsungnya reaksi antara DPPH dan senyawa antiradikal atau biasa disebut dengan waktu inkubasi. 
Berdasarkan hasil pengukuran didapatkan waktu inkubasi 30-34 menit, sedangkan panjang gelombang yang digunakan adalah 517,6 nm. Hasil penangkapan radikal bebas DPPH oleh ekstark uji dan vitamin E disajikan dalam Gambar 1.

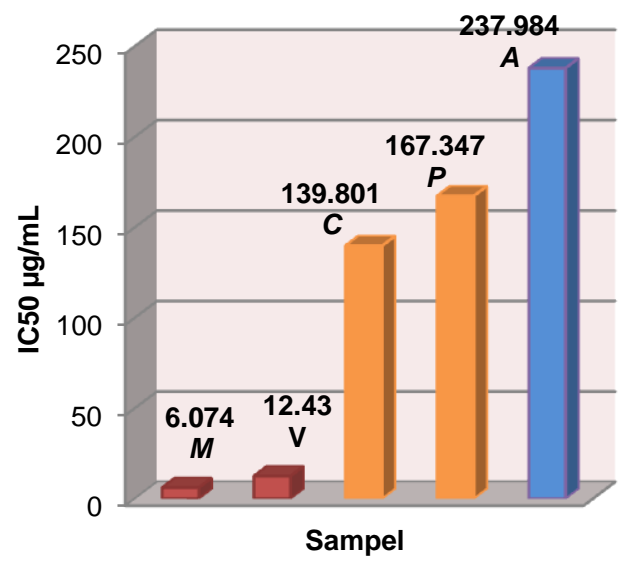

Gambar 1- Perbandingan $\mathrm{IC}_{50} \quad$ (M) Melaleuca leucadendron L, (V) Vitamin E, (C) Capsicum frutescens L, (P) Psidium guajava L dan (A) Anethum graveolens L, semakin rendah nilai $\mathrm{IC}_{50}$ maka semakin kuat aktivitas antioksidannya.

Perbedaan aktivitas antioksidan dari ekstrak yang diuji bisa dikarenakan perbedaan kandungan kimia dari tiap ekstrak. Aktivitas antiradikal dari ekstrak etanol buah Psidium guajava L, Melaleuca leucadendron L, Capsicum frutescens L, dan Anethum graveolens $\mathrm{L}$ dapat dikarenakan jenis dan kandungan senyawa-senyawa yang memiliki aktivitas antioksidan seperti fenolik. Untuk mengetahui hubungan antara kandungan fenolik dengan aktivitas antioksidan maka dilakukan uji kandungan fenolik total dalam sampel.

\section{Penentuan Kandungan Fenolik}

Penetapan kandungan fenolik total dilakukan dengan menggunakan pereaksi Folin-Ciocalteu. Pereaksi tersebut digunakan karena dapat bereaksi dengan semua jenis senyawa fenolik. Penetapan kandungan fenolik total dilakukan pada panjang gelombang maksimal $742,5 \mathrm{~nm}$ dan operating time-nya $40-$ 55 menit.
Berdasarkan hasil pengujian kandungan fenolik ekstrak uji, menunjukkan bahwa kandungan fenolik ekstrak buah Melaleuca leucadendron L (257,34 mg/g sampel) lebih besar dari pada ekstrak buah Psidium guaj $\mathrm{L}(23,73 \mathrm{mg} / \mathrm{g}$ sampel), Capsicum frutescens $\mathrm{L}(21,44 \mathrm{mg} / \mathrm{g}$ sampel), dan Anethum graveolens $\mathrm{L}(11,78$ $\mathrm{mg} / \mathrm{g}$ sampel) (Gambar 2).

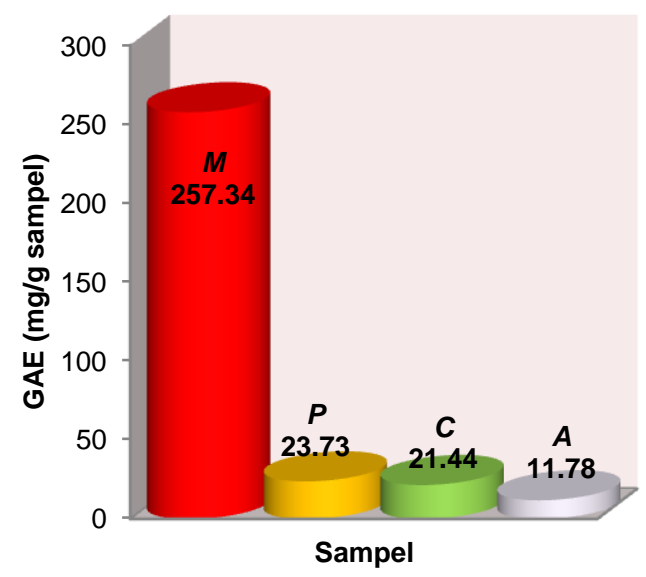

Gambar 2- Kandungan Fenolik total (M) Melaleuca leucadendron L, (P) Psidium guajava L, (C) Capsicum frutescens $\mathrm{L}$ dan (A) Anethum graveolens $\mathrm{L}$, konsentrasi stok $0,1 \%$ untuk $M$ dan $0,5 \%$ untuk $(P, C$ dan $A)$.

\section{Korelasi Kandungan Fenolik dengan Aktivitas Antioksidan}

Hasil penetapan aktivitas antioksidan dari ekstrak etanol buah Melaleuca leucadendron $\mathrm{L}$ memiliki aktivitas yang paling besar, kandungan fenolik total dari ekstrak buah Melaleuca leucadendron $L$ juga paling tinggi. Sedangkan ekstrak etanol buah Anethum graveolens L memiliki aktivitas antioksidan paling rendah, kadar fenolik total ekstrak Anethum graveolens $\mathrm{L}$ paling kecil jika dibandingkan dengan sampel yang lain. Berdasarkan hasil penelitian diketahui bahwa semakin tinggi kandungan fenolik maka akan memberikan aktivitas antioksidan yang semakin besar.

Hubungan antara kandungan senyawa fenolik total ekstrak etanol buah Psidium guajava L, Melaleuca leucadendron, Capsicum frutescens $\mathrm{L}$, dan Anethum graveolens $\mathrm{L}$ dengan nilai $\mathrm{IC}_{50}$-nya mempunyai koefisien korelasi $R^{2}=0,847(y=-0,478+196,6)$ (Gambar 3). 


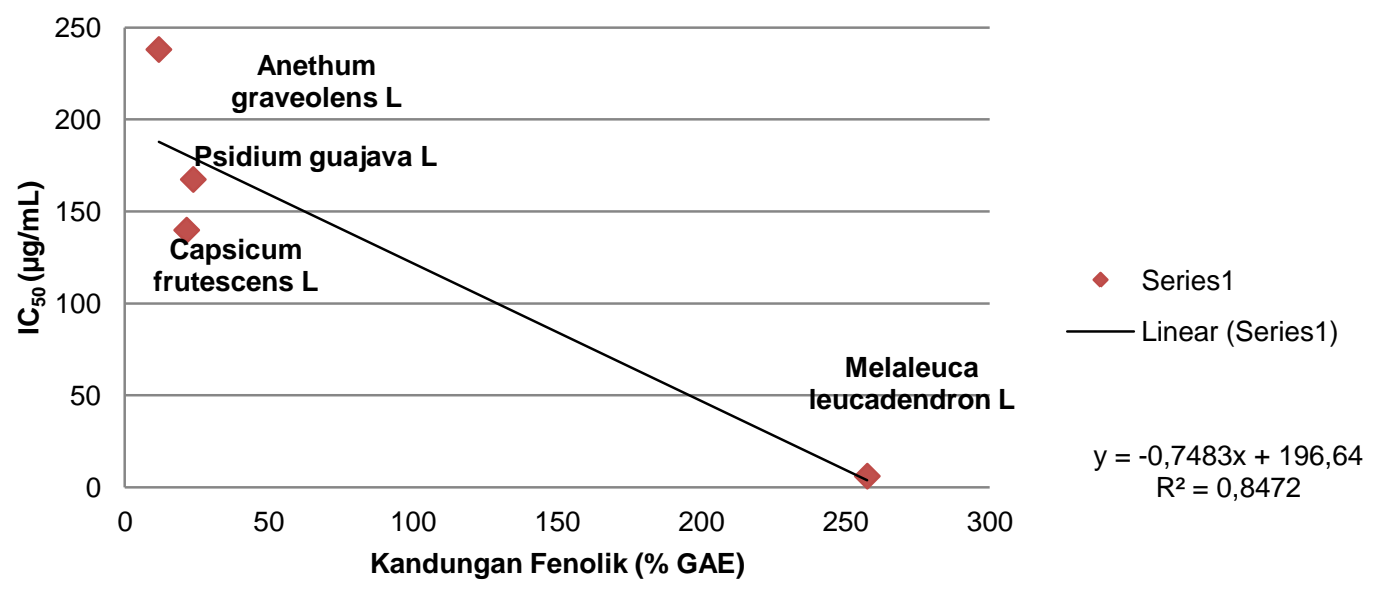

Gambar 3- Hubungan antara kandungan fenolik dengan aktivitas antioksidan Ekstrak Etanol Buah Psidium guajava L, Melaleuca leucadendron L, Capsicum frutescens L dan Anethum graveolens L.

Hasil ini menunjukkan bahwa $84,7 \%$ aktivitas antiradikal ekstrak etanol buah yang diuji merupakan kontribusi dari senyawa fenolik yang terkandung di- dalamnya seperti kuersetin, guajavarin, asam galat, leukosianidin, dan asam elagat pada buah Psidium guajava L (Sudarsono, 2002), Kapsaisin pada Capsicum frutescens $\mathrm{L}$ (Anonim, 2005), dihidrokapsaisin, homokapsaisin nor- dihidrokapsaisin dan homodihidro- kapsaisin (German Commission E, 1990 cit Wakhyulianto, 2005).

Aktivitas antioksidan Melaleuca leucadendron $\mathrm{L}$ berasal dari senyawa, Picetanol atau Astringinin (Tsuruga, et al., 1991 cit Bavaresco et al., 2002), yang diketahui mempunyai aktivitas antioksidan dan penangkap radikal bebas (Fauconneau et al., 1997 cit Bavaresco et al., 2002), flavonoida dan tannin (Thomas, 1992). Berdasarkan penelitian Zhang dan Lin (2009) tannin yang diekstrak dari buah Syzygium cumini mempunyai kemampuan dalam menangkap radikal DPPH, hasil ini menunjukkan bahwa tannin mempunyai kemampuan sebagai pendonor proton dan dapat berperan sebagai penghambat atau panangkap radikal bebas.

\section{KESIMPULAN}

Ekstrak etanol buah Melaleuca leucadendron $\mathrm{L}$ memiliki aktivitas antioksidan $\left(\mathrm{IC}_{50}=6,074 \mu \mathrm{g} / \mathrm{mL}\right)$, Capsicum frutescens $\mathrm{L}$ $\left(\mathrm{IC}_{50}=139,801 \mu \mathrm{g} / \mathrm{mL}\right)$, Psidium guajava $\mathrm{L}$ $(167,347 \mu \mathrm{g} / \mathrm{mL})$, Anethum graveolens L $(237,984 \mu \mathrm{g} / \mathrm{mL})$. Kandungan fenolik ekstrak buah Melaleuca leucadendron L (GAE $=257,34$ $\mathrm{mg} / \mathrm{g}$ sampel), Psidium guajava L $(23,73 \mathrm{mg} / \mathrm{g}$ sampel), Capsicum frutescens $\mathrm{L}(21,44 \mathrm{mg} / \mathrm{g}$ sampel), dan Anethum graveolens L (11,78 $\mathrm{mg} / \mathrm{g}$ sampel).

Terdapat korelasi sebesar $84,7 \%$ antara kandungan fenolik dengan aktivitas antiradikal, dimana semakin tinggi kandungan fenolik dalam sampel semakin tinggi pula aktivitas antioksidannya.

\section{DAFTAR PUSTAKA}

Amrun., M.H, Umiyah., Evi U.U., 2007, Uji Aktivitas Antioksidan Ekstrak Air dan Ekstrak Metanol beberapa Varian Buah Kenitu (Chrysophyllum cainito L.) dari Daerah Jember, Berk. Penel. Hayati, Vol 13, Hal 45, Bagian Biologi Farmasi, Program Studi Farmasi Universitas Jember, Jember.

Anonim, 2005, Antioksidan dan Radikal Bebas, (online), http://www.chem-istry.org/?sect=artikel\&ext=81, diakses tanggal 11 Mei 2006.

Bavaresco, L., Fregoni, M., Trevisan, M., Mattivi, F., Vrhovsek, U and Falchetti, R, 2002, The Occurrence of The Stilben Piceatannol in Grapes, Vitis 41, (3), 133.

Fauconneau, B., Waffo-Teguo, R., Huguet, F., Barrier, L., Decendit, A., Merillon, J.M, 1997, Comparative Study of Radical Scavenger and Antioxidant Properties of Phenolic Compound from Vittis vinevera Cell Cultures using In vitro Test, Life Sci, 61, 2103-2110.

German Commission E, 1990, http: //www.wrc.Net /wrcnet_content/herbalresources /materiamedica/Cayenne.htm 
Hariyatmi, 2004, Kemampuan Vitamin E sebagai Antioksidan terhadap Radikal Bebas pada Lanjut Usia, MIPA Vol. 14, No. 1, Januari 2004, Jurusan Pendidikan Biologi FKIP UMS, Surakarta.

Langseth, L., 1995, Oxidants, Antioxidans, and Disease Prevention, International Life Sciences Institutes (ILSI) Europe, Belgium.

Miean, K.H., Mohamed, S., 2001, Flavonoid (Myricetin, Quarcetin, Kaemfenol, Luteolin, and Apigenin) Content of Edible Tropical Plants, Journal of Agricultural and Food Chemistry 49, 3106311.

Misra, K., Seshadri, T.R., 1968, Chemical Components of the Fruit of Psidium Guajava. Phytochemistry 7, 641-645.

Montoro P, Braca A, Pizza C, Tommasi N.D, 2005, Structure Antioxidant Activity Relationship of Flavonoid Isolated from Different Plant Species. J Food Chemistry, 92, 349-55.

Prakash, A., 2001, Antioxidant Activity, Heart of Giant Recource, Vol 19, No.2.

Soeksmanto, A., Yatri, H., Partomuan, S., 2007, Kandungan Antioksidan pada Beberapa Bagian Tanaman Mahkota Dewa, Phaleria macrocarpa (Scheff) Boerl. (Thymelaceae), Biodiversitas, Volume 8 Nomor 2, Hal 92-93.

Sudarsono., Gunawan, D., Wahyuono, S., Argodonatus, I., dan Purnomo, 2002, Tanaman Obat II : Hasil Penelitian, sifat-sifat, dan penggunaan, 156-160, Pusat Studi Obat Tradisional UGM, Yogyakarta.

Thaipong, Kriengsak., Boonprakob, Unaroj., Crosby Kevin., Cisneroz-Zevallos, Luis., Byrne, Hawkins, D., 2006, Comparison of ABTS, FRAP, and ORAC assays for estimating antioxidant activity from guajava fruit extracts, Journal of Food and Analysis, 19 (2006) 669-675.

Thomas, A.N.S., 1992, Tanaman Obat Tradisional, Kanisius, Yogayakarta, 56-58.

Tsugura, T., Chun, Y.T, Ebizuka, Y., Sankawa, U, 1991, Biologically Active Constituent of Melaleuca luecadendron L: Inhibitor of Induced Histamin Realease from Rat Mast Cell, Chem Pharm Bull, 39, 3276-3278.

Velazquez, E., Tournie, HA., Buschiazzo Mordujovich de, P., Saavedra, G., Schinella, GR, 2003, Antioxidant Activity of Paraguayan Plant Extract, Fitoterapia, 74, 91-97.

Zhang, L.L., and Lin, Y.M, 2009, Antioxidant Tannin from Syzygium cumini Fruit, African Journal of Biotechnology, Vol 8, (10), 2301-2309.

Zou Y., Lu Y., Wei D., 2004, Antioxidant Activity of Flavonoid Rich Extratc of Hypericum perforatum L In Vitro, J Agric Food Chem 52: 5032-9. 